\title{
Investigating the Multivariate Granger Causality between Remittance, Government Expenditure and Economic Growth in Ethiopia
}

\author{
Engidaw Sisay Negash ${ }^{1} \quad$ Yang Dan $^{2} \quad$ Menda Mulushewa Akililu ${ }^{2}$ \\ 1. School of Economics, Zhejiang University, Hangzhou 310027, P. R. China \\ 2. Department of Economics, University of Cassino and Southern Lazio \\ Viale dell' Università, 03043 Cassino FR, Italy
}

\begin{abstract}
Several studies argued that international remittances have often been contributed to a significant source of finance to upsurge domestic investment for developing countries. Against this backdrop, this current article analyses a causal interdependency between remittance, government expenditure, and economic growth in Ethiopia covering the period from 1982 to 2017 by applying Toda and Yamamoto and Granger causality tests. Moreover, the Johansen-Juselius and an Auto-regressive Distributed Lag (ARDL) bounds-test approach was utilized to test the long-run co-integration relationship among the variables. Our findings confirmed that the series of variables has been jointly co-integrated in the long-run. The tests of the causality divulge that there was feedback in the causality between the remittance and economic growth in Ethiopia. We found that a unidirectional Granger causality links running from remittance to economic growth, and also a unidirectional causality running from government expenditure to economic growth. These causality results further suggested that the growth hypothesis which was assumed that the remittance and government expenditure was the main driving factor of determinants for economic growth in Ethiopia over the study periods and consequently, economic growth also the function of remittance and government expenditure.
\end{abstract}

Keywords: Remittances; Economic growth; Government Expenditure; Co-integration; Granger Causality; Ethiopia

JEL classification: C22; F24; F43; O55

DOI: $10.7176 / \mathrm{JESD} / 11-16-17$

Publication date:August $31^{\text {st }} 2020$

\section{Introduction}

Nowadays, one of the notable facts in the modern life is that majority of wealthy country people have experienced the remarkable standard of life estimated by a higher per-capita income at present than decades ago or a generation ago, or any time in the past (Brunow et al., 2015). Of course, there is a huge disparity in the growth rates among the nations in the world, some developed countries were gown on average around $1-2 \%$ per annual in recent periods; while in few developing countries have been experienced double-digit growth (Brunow et al., 2015). Throughout world history, cross-country migration has been contributed to a significant phenomenon for demographic change as well as played an important role in economic development (Cadena et al., 2015). For instance, according to the International Migration Report in 2017, 50 \% of international migrants are living in ten countries, among those US becomes the highest resided for migrants and then following Saudi Arabia and Germany second and third place, respectively (United Nations, 2017). Over the previous several decades, studies have been grown on the relationship between migration, remittance, and economic development (Cadena et al., 2015; Kumar, 2013; Rao and Takirua, 2010). Cross-country migration is a multiplex phenomenon that incorporates on a wide variety of movements of people from a country of origin to the other country of destination due to political, social or economic aspects which affect the normal lives an interconnected world (Bove and Elia, 2017; Brunow et al., 2015). In the normal way of life, international migrants might have benefited in different ways like improving the life standard, new personal and professional experience, ability to attain new knowledge, better satisfaction related to income, experience cultural exchange, businesses, and globalization (Brunow et al., 2015). Ever than before, in the past couple of decades, international migration was tremendously increasing in the global trend (Brunow et al., 2015). According to the United Nations, in 2000 there were 175 million people (2.8\% of the world's population) live outside their home country, after a decade the figure increased to 232 million in 2013 (Asatryan et al., 2017) and reaching to the peak 258 million in 2017, which measured $3.7 \%$ of the world population distribution (The World Bank, 2018; United Nations, 2017).

This trend has caused to intensity of the money and capital transfers from the destination country of the migrants to their origin countries, this can be known remittances (Goschin, 2014). Remittances are one of the external sources of non-reciprocal financial or in-kind transfers of foreign exchange earnings made by migrants directly to their families or communities served to a reasonable balance of payment and foreign currency reserves that curtail for investor panic for receiving countries (Abbas et al., 2017; Imai et al., 2014). It also used to contribute 
a positive influence on country credit ratings that provides a balanced source of foreign currency to promote investments and attribute substantial for development strategies (Imai et al., 2014). Data from the (World Bank, 2018) shows that the global remittance was officially recorded to reach US\$642 billion in 2018, up from under US\$18 billion in 1980 (Bang et al., 2016). Majority of these remittances were transmitted to developing countries that had grown substantially in the past decade to reached US\$325 billion by 2010 (World Bank, 2011) and after successive two years decline, it rebounded to touched a recent record of US\$485 billion in 2017, which was about $4.1 \%$ increase all regions from the former year 2016 (The World Bank, 2018).

These trends are mostly true in Africa both outflows of cross-country migrant population and incoming remittance money to the region, for instance by 2010 more than 31 million migrant workers live outside from the region and sending more than US\$40 billion to their families and communities equated about $2.6 \%$ of Africa's real GDP (Bang et al., 2016). However, the African development bank report suggests that the exact amounts of the remittance inflows to Africa including unrecorded inflows through informal and formal channels were supposed to be considerably higher than the recorded official's data (AfDB, 2019). For instance, according to the recent report by the World Bank, the formal channel of remittance inflows to the sub-Saharan African region in 2017 increased about $10 \%$ from about \$34 billion in 2016 (The World Bank, 2018). In most sub-Saharan African nations, remittances have to overshadow the official aid and foreign direct investment inflows in to the region (Nyamongoa et al., 2012; AfDB, 2019).

Ethiopia presents one of the decent examples of the SSA regional trends of remittance inflows that have shown increased substantially. The effect of remittance differs enormously across countries, as a result, the disparities in financial systems, the level of economic development, and migration patterns of the counties(VargasSilva, 2008). These differences are underlining required for specific country analysis to facilitate the cross-country assessments and established stylized facts. In this study, we concentrated on a single country case of Ethiopia. Therefore, we empirically investigate whether the inflows of remittance has triggered the economic growth in Ethiopia. This is mainly due to the fact that there are numerous assumptions that cause the recent economic growth in the country. However, remittances have not yet received sufficient examination even if the transmitted remittances into the country have shown rising gradually at a reasonable pace.

on the large scale of the earlier empirical literature studies (Abbas et al., 2017; Adams and Cuecuecha, 2013; Beyene, 2014; Goschin, 2014; Imai et al., 2014; Kumar, 2013; Makun, 2018; Meyer and Shera, 2016) posited that the inflows of remittances have a positive influence on the economic growth for the recipient country because it used to reduce the shortage of foreign currency crises, and intensify government expenditure for investment activities. Although, it further increases the circular movement of money supply that accessible for investment activity that supports decreasing unemployment (Adams and Cuecuecha, 2013; Alkhathlan, 2013). However, excessive money circulation into the economy could hamper negative economic growth due to the cause of aggravating the inflation rate (Abbas et al., 2017). Therefore, the paper is also examined whether there if such a relationship exists in Ethiopia.

Since the global remittance transmitting increased rapidly (Vargas-Silva, 2008), numerous studies have been focused to investigate the impacts of remittance previously. Nevertheless, the majority of the studies have been concentrated on transition and industrialized countries (Amega, 2018). In addition, the result of the reported from those studies was mixed which might be due to the study variables on the functional forms predicted, the length of the time period, the size of the country's economy, the heterogeneity of the estimation technique approached, and the efficiency of the econometric methodology employed (Abbas et al., 2017). Against these backdrops, it is essential to investigate a specific developing country case Ethiopia, as the conclusions from the other empirical studies result could not simply generalized to the Ethiopian scenario. Furthermore, as far as our knowledge is concerned, there is no study has been carried out in the case of Ethiopia with the focus of remittance, government spending, and economic growth. Consequently, this present study investigates the variables in time series form particular properties by using numerous unit roots test methods such as, the Augmented Dickey Fuller (ADF), ADF with the generalized least squares (DF-GLS) and Phillips and Perron (PP) tests. Moreover, the ARDL model extended by (Pesaran et al., 2001), the (Johansen, 1988), and (Johansen and Juselius, 1990) methods were utilized to test for the long run co-integration between the study variables. Finally, the newly modified form of (Toda and Yamamoto, 1995) Granger causality test was conducted to test the causality function of the variables in the model. The organization of the remaining part of the paper is next to the introduction in section 1 section 2 described stylised facts of Ethiopia. Section 3 principally focuses on the data and methodological procedures used to examine the Granger causality. Section 4 discusses the empirical results, and Section 5 presents the conclusions of the study.

\section{Stylised Facts on Ethiopia}

The economy of Ethiopia is mixed and developing with a large-scale public investment (NBE, 2018). It remains East Africa's fastest-growing economy and Africa's second most populated country, with an US\$883 GDP per capita in 2017 (NBE, 2018). Agriculture is the backbone of the Ethiopian economy, for instance in 2005 which accounts for $48 \%$ of the country's GDP, $80 \%$ of the total employment and more than $83 \%$ of the total exports 
revenue (Matouš et al., 2013) followed by service and manufacturing sectors have contributed 39\% and $13 \%$ for GDP, respectively (NBE, 2006). After the successful implementation of a new Growth and Transformation Plan (GTP) in 2010, the economy of Ethiopia gradually changed due to the share of agriculture to GDP declined $34 \%$ in 2017 from 42\% in 2010 (MOFED, 2010; NBE, 2018). The service and manufacturing sectors have shown improvement as the share of GDP to $39.2 \%$ and $27 \%$ in 2017 , respectively (NBE, 2018). For more than a decade, the Ethiopian economy has grown on average over $10.6 \%$ at an annual in real terms, however, the GDP growth decline in 2017/18, due partially to political uncertainty, civil unrest and structural policy adjustments that include fiscal consolidation used to stabilize the external public debt (AfDB, 2019). As shown in Table 1, the GDP growth, remittance, and government expenditures were gradually increasing from year to year at steady shifts. In the same way, the government policy direction was changed to transformation the development plan through enhancing the participation of private owned expenditures in the manufacturing sector to stimulate export-led growth and more emphasise to modernizing the agriculture sector which has been dominated the country's economy (NBE, 2018). The private investment has focused on infrastructural projects which designed to boost the country economy development target, including energy generation, telecommunications, industrial parks, trade, social development, transport infrastructure development, and encouraging growth to diversify the economy (AfDB, 2019).

Table 1:Trends in the annual growth rate of the GDP, remittance, and government expenditure as a percentage of GDP in Ethiopia during the 1982-20117 periods.

\begin{tabular}{lccc}
\hline Years & $\begin{array}{c}\text { GDP growth } \\
\text { rate }\end{array}$ & $\begin{array}{c}\text { Remittance } \\
\text { inflow's }\end{array}$ & $\begin{array}{c}\text { Government } \\
\text { expenditure }\end{array}$ \\
\hline $1982-89$ & 2.35 & 0.38 & 16.11 \\
$1990-99$ & 2.66 & 0.44 & 11.17 \\
$2000-09$ & 8.10 & 1.50 & 13.66 \\
2010 & 12.55 & 2.47 & 9.19 \\
2011 & 11.18 & 2.24 & 10.32 \\
2012 & 8.65 & 1.79 & 9.00 \\
2013 & 10.58 & 2.17 & 9.20 \\
2014 & 10.26 & 3.19 & 9.00 \\
2015 & 10.39 & 2.16 & 11.10 \\
2016 & 7.56 & 1.55 & 11.10 \\
2017 & 10.25 & 2.10 & 12.30 \\
\hline
\end{tabular}

Source: World Bank, World Development Indicators (2017) and National Bank of Ethiopia (2017 and 2018)

Due to the government expansionary policy, Ethiopia has been in an appalling state of foreign exchange crisis for the last few years (AfDB, 2019). In 2018, the recent public debt-to-GDP ratio reached a peak of $61.8 \%$, thus the economy remains at a high risk of public debt suffering increases. In the preceding year, a relatively reduced trade deficit and due to strong growth in remittances helped improve the current account deficit from 8.1\% of GDP in 2016 to $6.0 \%$ in 2017 (AfDB, 2019; NBE, 2018). Ethiopia is one of the SSA countries, being the highest in position in the top five SSA countries that registered the maximum migrant stocks by the mid-year of 2017 (Cooper and Esser, 2018). According to the World Bank estimates, in 2017 more than 3.2 million diaspora Ethiopians living abroad in 85 different countries and playing extremely important contributions to the country by sending back remittances (The World Bank, 2018). However, the remittance data in Ethiopia fluctuate by sources for example, (The World Bank, 2011a), reported that the inflows of the remittance were $1.3 \%$ of the GDP in 2009. According to the Bank's data, the remittance grew gradually from US\$27 million during 1995 to US\$53 million by 2000 and stood above seven times in the successive years to reached \$387 million in 2010 (NBE, 2010; The World Bank, 2011 b). However, the data reported by Central Bank of Ethiopia shows that the figure substantially higher $\$ 661$ million in the 2010(NBE, 2010) sharply rose to US\$1,796 million in 2014, and reached the peak to over US\$4.4 billion by 2017 about $45 \%$ increased to reached in 2017(NBE, 2018). 


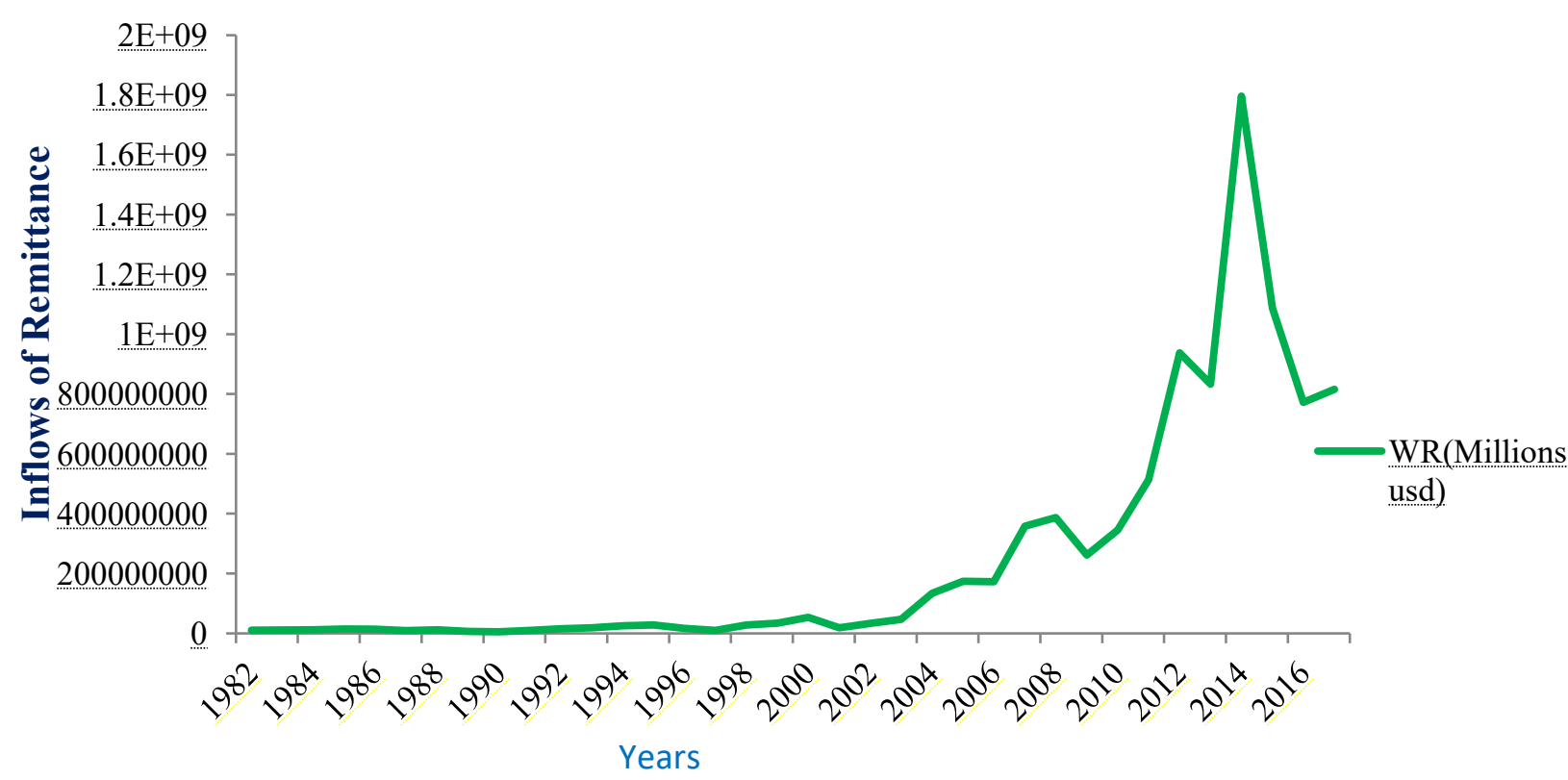

Figure 1 Trends in the inflow of Remittance in Ethiopia during 1982-2017

Source: World Bank, World Development Indicators (2018)

The data plotted in Figure 1, was obtained from the World Bank migration and remittances shows that the dynamics of remittances during the 1982-2017 period. The remittances inflows tended to low before the 2004 period. However, since 2004 the inflows of remittance growth rate have shown different magnitudes.

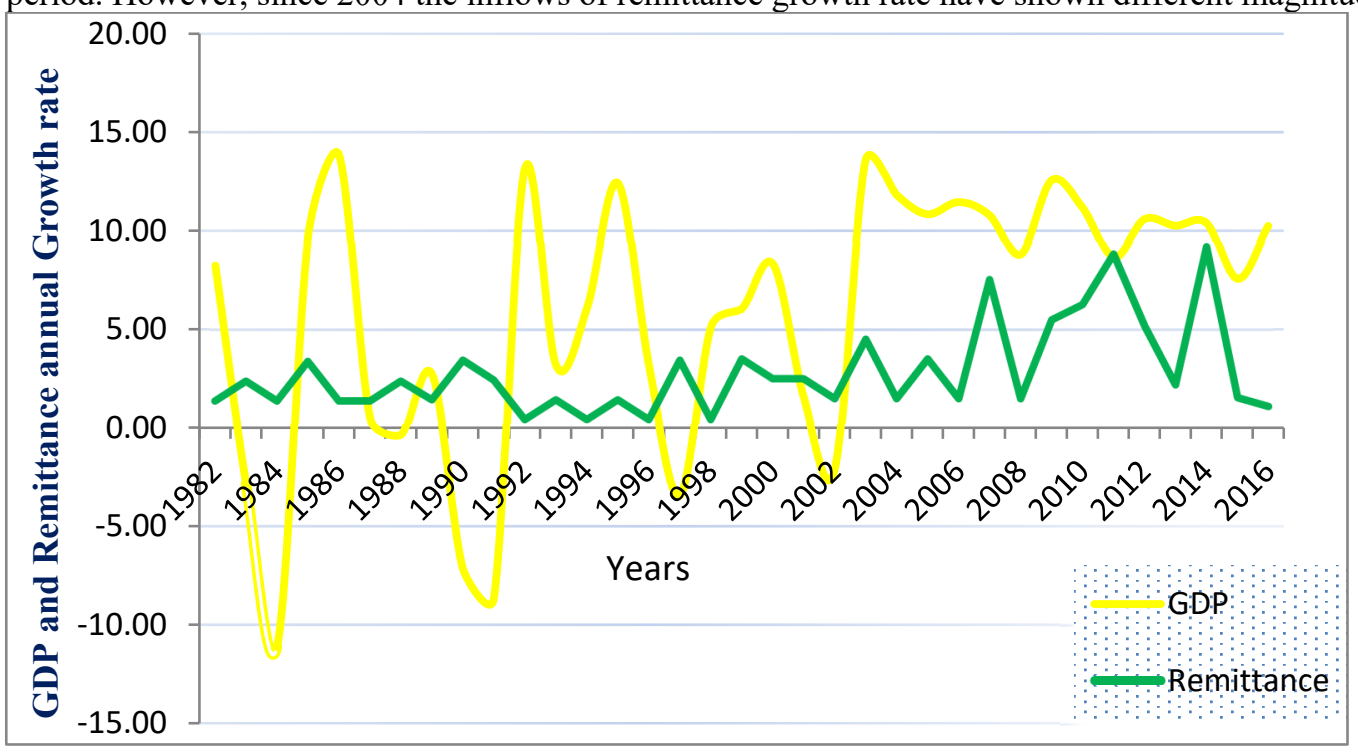

Figure 2 Trends of the GDP growth rate and annual inflow of remittance during 19982-2017

Source: World Bank, World Development Indicators (2018)

Figure 2, reports the trend of the GDP growth and the inflows remittances in Ethiopia during the same period 1982-2017. The figure shows that remittances increased slightly when the GDP growth rate rises continuously since 2004.

\section{Data and Methodology}

\subsection{Data Sources}

The key role of this study was to empirically investigate the nexus between GDP growth on the proxies of economic growth and the inflows of international remittances in Ethiopia. Due to the availability of all the datasets, the study covers only 36 years of observations collected from various sources from 1982-2017. The time period choice was constrained by the availability of the data included in the study. The study was initiated based on the assumption that economic growth could cause the external sources capitals in the form of international remittances from cross- border migrants working in foreign countries. The GDP growth was considered as an explained variable and the other remittance, government expenditure, exports, rural population growth, and the inflation rate 
was used as the instrumental explanatory variables. The GDP data was measured as \% of annual growth rate, export and remittances data were measured in millions of us dollars at a current nominal rate. The data of rural population growth measured as (annual \%) of growth and considered the growth of the urbanization of the country and decline the population lives in the rural area of the country who supports the growth rate of the country and the government expenditures were used as \% of GDP. Inflation rate data was measured the annual growth rate in the consumer price index (CPI). The data were collected, government expenditures from Central Bank of Ethiopia annual report in each successive years (NBE, 2018) and GDP, remittance, export, rural population growth, and inflation rate were from the World Bank database, World Development Indicators (The World Bank, 2018). The summary of the descriptive statistics of all the variables is given in Table 2.

Table 2: Summary of the descriptive statistics

\begin{tabular}{lcccccc}
\hline & GDP & WR & GE & EXP & RPG & INF \\
\hline Mean & 5.77 & 17.90 & 12.61 & 21.11 & 2.64 & 8.92 \\
Median & 8.27 & 17.21 & 12.56 & 20.75 & 2.67 & 7.88 \\
Maximum & 13.86 & 21.30 & 19.13 & 22.59 & 3.31 & 44.36 \\
Minimum & -11.14 & 15.46 & 7.73 & 20.09 & 1.90 & -9.81 \\
Std. Dev. & 6.691 & 1.80 & 3.41 & 0.88 & 0.42 & 11.36 \\
Jarque-Bera & 4.78 & 3.73 & 3.15 & 4.22 & 2.12 & 15.11 \\
Observations & 36 & 36 & 36 & 36 & 36 & 36 \\
\hline
\end{tabular}

\subsection{Unit Root Tests}

In this study, the main purpose of performing the unit root process was to test for stationarity property in our timeseries data. Mostly, in the time series analysis, it is crucial to identify the series of data generating process (DGP). The seminal study by ( Granger and Newbold, 1974) who focused on the spurious regressions proposed that if non-stationary data involved in time series, it might be lead to the invalid outcome of the analysis of the regression model. During the time series data analysis, when stationarity property is assumed the data should be integrated into the levels of order zero I(0)(Rao and Takirua, 2010). Consequently, the parameters are like variance, and mean could not change over time. In econometrics there are several econometrics unit root (s) test techniques; however, this study was employed commonly used approach by most economists such as ADF, ADF-GLS, and PP tests. The ADF test was used to explore the DGP of the various variables under the study consideration. For instance, a seminal paper by (Agiakoglu and Newbold, 1992) suggested that the ADF approach is prone against under rejecting the null hypothesis of the unit root, particularly if the time series data that has trend stationarity with a structural break. Likewise, the ADF-GLS test was employed because it is more efficient and powerful than the ADF approach if the study supposed to capture the sample size constraints. At last, to corroborate the effects of the ADF and ADF-GLS test, the PP stationarity test was employed as the robustness of the alternative models result. This technique is specifically important due to the other unit root test methods have exceptional properties to test the stationarity. The PP test argued that the structural breaks must be capture into deliberation when directing the unit root tests if the other stationarity tests fail to identify the unit root of the variables through structural breaks (Appiah, 2018).

\subsection{Cointegration Test}

The Cointegration investigation of non-stationary variables of the time series draws from the works of (Granger, 1969; 1981), (Granger and Weiss, 1983), and (Engle and Granger, 1987). In this analysis, the series of two and more variables are supposed to be co-integrated, if and only if there is the presence of at least one stable long-run equilibrium association between them (i.e., when they have joint trends in the long run). If cointegration is established that the DGP includes a unit root process thus the question that derives up whether there is any stable long-run equilibrium association among the variables (Appiah, 2018). Therefore, there is a possibility that could have common trends happen within the series of the variables as the group. Hence, if this occurs to be part of the situation, in any function condition based on the series differences that might possible to incorrectly specified to miss-leading the information that culminates in a spurious result in the regressions analysis (Engle and Granger, 1987).

Nevertheless, (Engle and Granger, 1987) extended their study and identified that if a time series variables convert stationary after the first difference in the linear combination from the non-stationary series, in this scenario the series of the variables could be jointly cointegrated. In econometrics model, there are several cointegration methods, but the study employed Engle and Granger (1987) two-step test methods were adopted to demonstrate whether the variables have a stable common cointegrating relationship (Engle and Granger, 1987). However, as described in the numerous empirical literature studies, one fundamental striking fact well-known in this cointegration test that measures only one cointegration relationship, and hence assumed that this method might not yield a consistent outcome when more than one cointegration relationships exist (Appiah, 2018). Therefore, to estimate the reliable results we employed more than one method such as (Johansen, 1988),(Johansen and Juselius, 
1990) cointegration methods, and the ARDL bounds test analysis developed by (Pesaran et al., 2001). The estimation of the Johansen (1988) and Johansen-Juselius (1990) cointegration approaches were essentially developed used to overcome the limitation of as an enhancement of over the (Engle and Granger, 1987) two-step techniques that the sample sizes covering from 30 - 80 data edges. Besides, the ARDL cointegration also could handle endogeneity matters and can demonstrate the number of cointegrating associations, when more than two or more series of the variables being studied (Pesaran et al., 2001).

However, if any of the variables in the data has stationary at I(2), the ARDL model cannot run (Pesaran et al., 2001). The ARDL models were established, assuming that all the variables normalized as explained: annual GDP growth, workers' remittance, government expenditure, total exports, rural population growth, and inflation rate (Table 5). For the intention of parsimony, only one ARDL expression out of the six models as described in this paper. Hence, with respect to the ARDL expression (Model 1) for co-integration to the GDP was specified as follows:

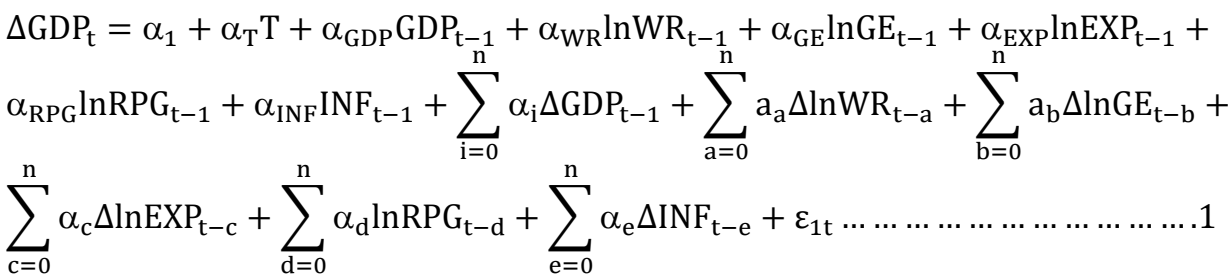

Where: GDP $_{t}$ denotes the GDP growth at time $t$; T means time trend; ln represents natural logarithm; WRt denotes workers' remittance at time $t$; $\mathrm{GE}_{t}$ denotes government expenditure; $\mathrm{EXP}_{\mathrm{t}}$ denotes total export; $\mathrm{RPG}_{\mathrm{t}}$ and $\mathrm{INF}_{\mathrm{t}}$ represent rural population growth and inflation rate, respectively. Besides, $\Delta$ is representing the term of the first difference operator, and st1 denotes a stochastic error term. Except for the GDP and INF, the other variables were expressed in the natural logarithmic form. The maximum lags of the specification of the ARDL model were selected using the Akaike information criterion (AIC) and the Schwarz Information Criterion (SIC). Thus, the various coefficients of the joint significance level of the lagged one-period series were established with the situation of the standard F-statistic. The distributions of an asymptotic critical value are derived for the suitable causes which determine the explanatory variables either I (0) or I (1) or mutually co-integrated. The null hypothesis for no cointegration and an alternative hypothesis for cointegration within the variables are specified as follows:

$H_{0}: \alpha G D P=\alpha W R=\alpha G E=\alpha E X P=\alpha R P G=\alpha I N F=0$

Against the alternative hypothesis for cointegration:

$H_{I}: \alpha G D P \neq \alpha W R \neq \alpha G E \neq \alpha E X P \neq \alpha R P G \neq \alpha I N F \neq 0$

To corroborate whether the variables are jointly cointegrated or no cointegrated, (Pesaran et al., 2001) proposed two sets of critical values for any given series of variables. Hence, if computed F-statistic falls below the lower bound critical values, i.e. [I (0)], then accept $\mathrm{H}_{0}$ or no joint cointegration among the series of the variables, which suggests that the group of series variables does not cointegrate. However, if calculated F-statistic lies upper bound critical values, i.e. [I (1)], then rejects $\mathrm{H}_{\mathrm{o}}$ no jointly cointegration and hence, rather accept $\mathrm{H}_{1}$ concludes that the series is jointly cointegrated in the long period. Finally, if the calculated F-statistic places between the two sets of critical bounds, then the conclusion becomes inconclusive results for the study (Pesaran et al., 2001).

After corroborating the variables cointegrated in the long-run in the ARDL models established as equation (1) then, an error correction model (ECM) was developed which describes the dynamics of the short-run impact in the following forms.

$\Delta \mathrm{GDP}_{\mathrm{t}}=\alpha_{0}+\sum_{\mathrm{i}=1}^{\mathrm{p}} \beta_{1 \mathrm{i}} \Delta \mathrm{GDP}_{\mathrm{t}-\mathrm{i}}+\sum_{\mathrm{i}=1}^{\mathrm{n}} \beta_{2 \mathrm{i}} \Delta \operatorname{lnWR}_{\mathrm{t}-\mathrm{i}}+\sum_{\mathrm{i}=1}^{\mathrm{n}} \beta_{3 \mathrm{i}} \Delta \mathrm{inGE}_{\mathrm{t}-\mathrm{i}}+\sum_{\mathrm{i}=1}^{\mathrm{n}} \beta_{4 \mathrm{i}} \Delta \ln \operatorname{LXP}_{\mathrm{t}-\mathrm{i}}+$

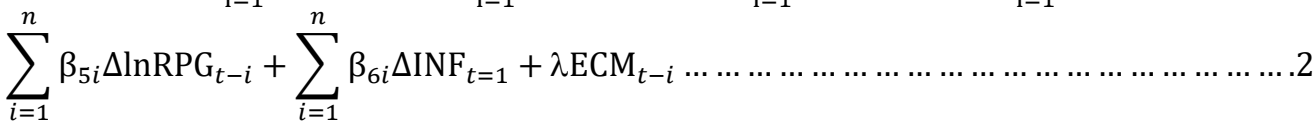

Where, $\mathrm{ECM}_{\mathrm{t}-\mathrm{i}}$ denotes the error correction term; $\beta 1-\beta 6$ are short-run coefficients and $\lambda$ represents the coefficient of ECM, it should be negative and statistically significant and determines how fast the variables converge to the steady equilibrium within the model's aftershock observed (Engle and Granger, 1987; Pesaran et al., 2001).

\subsection{Granger Causality Test}

The given conditions associated through conducting the conventional Granger-causality-test, determining whether the series are cointegrated, thus the test of Toda and Yamamoto (1995) (TY) circumvents the limitations linked with determining the cointegration and the unit root relation status the series before evaluating the specific model required for Granger-causality test. The TY approach fits the vector auto-regressive (VAR) model to the series of the variables at the levels, it is used to reduce the risk related to the trend of incorrectly determining the integration 
order of the variables series (Mavrotas and Kelly, 2001; Wolde-Rufael, 2005). However, in the basic feature of the TY method performing the integration order is not required before the test of the causality being conducted. In other arguments, the long-run causality-test intuitively augments the correct VAR order (maximal lag, k) by the optimal integration order (optimal difference of $\mathrm{d}_{\max }$ ), confirming that the statistical test for Granger-causality has the standard asymptotic distribution (Appiah, 2018; Wolde-Rufael, 2010). Therefore, the TY causality approach could be more pragmatic to determine whether the series of the variables are integrated I (0), I (1), even I(2). Furthermore, Wolde-Rufael (2005) rightly argues that the TY causality test prevents the deficiencies that come related to the sample size and power misleading outcomes efficiently associated with the Granger-causality test methods. The TY test adapts a Modified Wald test (MWALD) for the test of improved causality and thus, establish the test stat that has a chi-square asymptotic distribution, with respect to the $\mathrm{k}$ degrees of freedom to the limit while the VAR augmented in the $\mathrm{k}+\mathrm{d}_{\max }$ in the levels estimated with the optimal level of integration. To commence the TY description of the test of the Granger non-causality estimate for the numerous models are described in the following system equations. For the determination of parsimony, merely two models were expressed in this paper: Model 1: Economic growth and workers' remittances:

$$
\begin{aligned}
& \mathrm{GDP}_{\mathrm{t}}=\alpha_{0}+\sum_{\mathrm{i}=1}^{\mathrm{k}} \beta_{1 \mathrm{i}} \mathrm{GDP}_{\mathrm{t}-\mathrm{i}}+\sum_{\mathrm{j}+1}^{\mathrm{dmax}} \beta_{2 \mathrm{j}} \mathrm{GDP}_{\mathrm{t}-\mathrm{j}}+\sum_{\mathrm{i}=1}^{\mathrm{k}} \phi_{1 \mathrm{i}} \ln \mathrm{WR}_{\mathrm{t}-\mathrm{j}}+\sum_{\mathrm{j}=\mathrm{i}+1}^{\mathrm{dmax}} \phi_{2 \mathrm{j}} \operatorname{lnWR}_{\mathrm{t}-\mathrm{j}}+ \\
& \sum_{i=1}^{k} \gamma_{1 i} \operatorname{lnGE} t-j+\sum_{j=i+1}^{d m a x} \gamma_{2 j} \operatorname{lnGE} t-j+\sum_{i=1}^{k} \lambda_{1 i} \ln E X P_{t-j}+\sum_{j=i+1}^{d m a x} \lambda_{2 j} \ln E X P_{t-j}+ \\
& \sum_{i=1}^{k} \delta_{1 i} \operatorname{lnPRG}_{t-j}+\sum_{j=i+1}^{d m a x} \delta_{2 j} \operatorname{lnRPG}_{t-j}+\sum_{i=1}^{k} \theta_{1 i} I N F_{t-j}+\sum_{j=i+1}^{d m a x} \theta_{2 j} I N F_{t-j}+\varepsilon_{1 t} \ldots \ldots \ldots \ldots \ldots \ldots 3
\end{aligned}
$$

Model 2: Workers' remittances and Economic growth:

$$
\begin{aligned}
& \operatorname{lnWR} R_{t}=\alpha_{0}+\sum_{i=1}^{k} \phi_{1 i} \ln W R_{t-j}+\sum_{j+1}^{d m a x} \phi_{2 j} \operatorname{lnWR}_{t-j}+\sum_{i=1}^{k} \beta_{1 i} G P_{t-j}+\sum_{j=i+1}^{d m a x} \beta_{2 j} G D P P_{t-j}+ \\
& \sum_{i=1}^{k} \gamma_{1 i} \operatorname{lnGE} t-j+\sum_{j=i+1}^{d m a x} \gamma_{2 j} \operatorname{lnGE} t-j+\sum_{i=1}^{k} \lambda_{1 i} \ln \operatorname{EXP}_{t-j}+\sum_{j=i+1}^{d m a x} \lambda_{2 j} \operatorname{lnEXP_{t-j}}+ \\
& \sum_{i=1}^{k} \delta_{1 i} \ln P R G_{t-j}+\sum_{j=i+1}^{d m a x} \delta_{2 j} \operatorname{lnRPG}_{t-j}+\sum_{i=1}^{k} \theta_{1 i} I N F_{t-j}+\sum_{j=i+1}^{d m a x} \theta_{2 j} I N F_{t-j}+\varepsilon_{1 t} \ldots \ldots \ldots \ldots
\end{aligned}
$$

Where all the variables were defined earlier in equation $2, \varepsilon 1 \mathrm{t}$ and $\varepsilon 2 \mathrm{t}$ denoted a disturbance term supposed to be uncorrelated and mean zero. From Eq. (3), if $\phi_{1 \mathrm{i}} \neq 0 \forall_{\mathrm{i}}$ a unidirectional Granger causality would be established from workers' remittance to economic growth in the long run. In the same way, from Eq. (4), if $\beta_{1 i} \neq 0 \forall_{\mathrm{i}}$ a unidirectional Granger-causality could run from economic growth to workers remittance. Nevertheless, if $\phi_{1 \mathrm{i}} \neq 0 \forall_{\mathrm{i}}$ and $\beta_{1 \mathrm{i}} \neq 0 \forall_{\mathrm{i}}$ established jointly from eq. 3 and 4 , respectively there should be a two-way directional Granger causality established among workers' remittance and economic growth in the model. Finally, if $\phi_{1 \mathrm{i}}=0 \forall_{\mathrm{i}}$ and $\beta_{1 \mathrm{i}}=0 \forall_{\mathrm{i}}$ from 3 and 4 there is no Granger causality between the series.

\section{Empirical Results}

\subsection{Unit Root Tests}

The analysis of unit root properties of all the time series specification variables involved under the model was captured by the ADF, DF-GLS, and PP tests. 
Table 3: Unit root test for stationarity

\begin{tabular}{llll}
\hline Variables & ADF & PP & DF-GLS \\
\hline GDP $_{\mathrm{t}}$ & $-4.23(-2.94)$ & $-4.16(-2.94)$ & $-4.11(-1.95)$ \\
$\operatorname{lnWR}_{\mathrm{t}}$ & $-0.40(-2.94)$ & $-0.14(-2.94)$ & $-0.08(-1.95)$ \\
$\operatorname{lnGE}_{\mathrm{t}}$ & $-2.54(-2.95)$ & $-2.00(-2.94)$ & $-2.39(-1.95)$ \\
$\operatorname{lnEXP}_{\mathrm{t}}$ & $-0.49(-2.95)$ & $-0.22(-2.94)$ & $-0.35(-1.95)$ \\
$\operatorname{lnRPG}_{\mathrm{t}}$ & $-0.22(-2.95)$ & $-0.37(-2.94)$ & $-0.41(-1.95)$ \\
$\mathrm{INF}_{\mathrm{t}}$ & $-4.55(-2.94)$ & $-4.56(-2.94)$ & $-4.58(-1.95)$ \\
$\Delta \mathrm{GDP}_{\mathrm{t}}$ & $-9.13(-2.94)$ & $-15.48(-2.95)$ & $-6.51(-1.95)$ \\
$\Delta \operatorname{lnWR}_{\mathrm{t}}$ & $-6.27(-2.95)$ & $-6.71(-2.95)$ & $-6.35(-1.95)$ \\
$\Delta \operatorname{lnGE}_{\mathrm{t}}$ & $-3.96(-2.95)$ & $-3.71(-2.95)$ & $-4.00(-1.95)$ \\
$\Delta \operatorname{lnEXP}_{\mathrm{t}}$ & $-4.50(-2.95)$ & $-4.53(-2.95)$ & $-4.45(-1.95)$ \\
$\Delta \operatorname{lnRPG}_{\mathrm{t}}$ & $-4.33(-2.95)$ & $-4.34(-2.95)$ & $-3.19(-1.95)$ \\
$\Delta \mathrm{INF}_{\mathrm{t}}$ & $-8.18(-2.95)$ & $-14.85(-2.95)$ & $-7.56(-1.95)$ \\
\hline
\end{tabular}

Notes: Figures in brackets are critical values at the $5 \%$ level. While in tests for the levels intercept and trend are included, the trend is not present in the tests for the first differences of the variables. The null hypothesis in the $\mathrm{ADF}, \mathrm{PP}$, and ADF-GLS is assumed that the variable contains a unit root. $\Delta$ represents the first difference.

The calculated results of all the unit root test techniques confirmed the series of the variables were mixed integrated order I[0] and I[1]. As the result reported in Table 3, the t-statistics of the unit root test at levels were above the critical values for the variables of the GDP and INF with all the three approaches, thus the $\mathrm{H}_{\mathrm{o}}$ of unit root at the $(5 \%)$ significance level was rejected. Hence the variables of the GDP and INF were integrated order zero. However, the rest of the variables WR, GE, EXP, and RPG were accepted the $\mathrm{H}_{\mathrm{o}}$ whereas the t-statistics of the unit root test in the first difference were above the critical values, thus the $\mathrm{H}_{0}$ of the unit root at $(5 \%)$ significance level was rejected so that the variables are integrated of order one (Table 3).

\subsection{Result of Cointegration test}

Moreover, the long-run association among the variables under the study consideration was examined. To make sure the robustness of the cointegration (Johansen, 1988), (Johansen and Juselius, 1990) approach, and the ARDL bounds test by (Pesaran et al., 2001) were employed to this end for the presence of the cointegration. The Johansen and Juselius results for the cointegration test are presented in Table 4. As which the null hypothesis of the longrun relationship at most three cointegrating at 5\% significance level was accepted due to the Trace statistic of (23.04850) and Max- Eigen statistics (13.69017) were obtained less than the calculated critical values of (29.79707) and (21.13162), respectively (Table 4 panel A and B) therefore, based on the result we can conclude that all the variables were jointly cointegrated in the long-run.

Table 4: Johansen and Juselius results for the cointegration test. Panel A

\begin{tabular}{|c|c|c|c|}
\hline Hypothesized no. of CE(s) & Trace Statistic & 0.05 Critical Value & P-value ${ }^{b}$ \\
\hline None $^{a}$ & 423.9833 & 95.75366 & 0.0001 \\
\hline At most $1^{a}$ & 162.9363 & 69.81889 & 0.0000 \\
\hline At most $2^{a}$ & 71.60689 & 47.85613 & 0.0001 \\
\hline At most 3 & 23.04850 & 29.79707 & 0.2437 \\
\hline At most 4 & 9.358338 & 15.49471 & 0.3333 \\
\hline At most 5 & 2.681708 & 3.841466 & 0.1015 \\
\hline
\end{tabular}

Panel B

\begin{tabular}{|c|c|c|c|}
\hline Hypothesized no. of CE(s) & Max-Eigen Statistic & 0.05 Critical Value & $P$-value ${ }^{b}$ \\
\hline None $^{\mathrm{a}}$ & 261.0470 & 40.07757 & 0.0001 \\
\hline At most $1^{\mathrm{a}}$ & 91.32940 & 33.87687 & 0.0000 \\
\hline At most $2^{a}$ & 48.55839 & 27.58434 & 0.0000 \\
\hline At most 3 & 13.69017 & 21.13162 & 0.3910 \\
\hline At most 4 & 6.676630 & 14.26460 & 0.5281 \\
\hline At most 5 & 2.681708 & 3.841466 & 0.1015 \\
\hline
\end{tabular}

${ }^{a}$ Denotes rejection of the hypothesis at the 0.05 test level.

${ }^{\mathrm{b}}$ MacKinnon-Haug-Michelis (1999) p-values.

After performing the Johansen's cointegration, the ARDL bounds test was carried out to explore to corroborate the Johansen's cointegration results. Once again, since the study used annual time series data, before running the ARDL cointegration relationship identifying optimal lag length using the lag length criteria required for the cointegration test (Makun, 2018). Hence, initially, we start to evaluate from the maximum of the lag four and then decrease to lag three, two, and at last lag one. Therefore, lag 1 was selected as the maximum lag length 
for the ARDL cointegration model using the SBC. The estimation result of the AIC and SBC values of all the lag figures with the LM test result for serial correlation presented in Appendix Table1. The numerous ARDL models were estimated with normalized that all the variables substituted in the response variables however, this study emphasis merely on the model's economic growth measured as (GDP) and workers' remittance in the dependent variables. The models were estimated through unrestricted constant and trend. Thus, the computed F-statistics (5.8053), (9.0110), (4.2920), (5.4207), and (6.2085) were greater than the higher bound critical value I [1] $=4.25$ at the standard significance level of $5 \%$ (Table 5). Based on the result, we reject no cointegration of the $\mathrm{H}_{0}$; rather we accept the $\mathrm{H}_{1}$ then determine that there were stable cointegration relations among the variables (Table 5). Overall, the ARDL cointegration bound relation of the F-test was assumed to be carried out on the regression analysis the model that does not affect by any serial correlation issues with respective of the AIC and SBC values.

Table 5: ARDL Bounds Testing Results for Co-integration

\begin{tabular}{llc}
\hline Dependent Variable & Function & F- test statistic [p-value] \\
\hline Model 1 & F [GDP| LNWR, LNGE, LNRPG, LNEXP, INF] & $5.8053[0.0001]^{\mathrm{b}}$ \\
Model 2 & F [LNWR| GDP, LNGE, LNRPG, LNEXP, INF] & $9.0110[0.0002]^{\mathrm{b}}$ \\
Model 3 & F [LNGE| GDP, LNWR, LNRPG, LNEXP, INF] & $4.2920[0.0064]^{\mathrm{b}}$ \\
Model 4 & F [LNRPG| GDP, LNWR, LNGE, LNEXP, INF] & $5.4207[0.0123)^{\mathrm{b}}$ \\
Model 5 & F [LNEXP| GDP, LNWR, LNGE, LNRPG, INF] & $6.2085[0.0050]^{\mathrm{b}}$ \\
Model 6 & F [INF| GDP, LNWR, LNGE, LNRPG, LNEXP] & $3.3835[0.0014]$ \\
\hline \multicolumn{1}{c}{ Significance } & Critical Value Bounds & \\
\hline $10 \%$ & I(0) Bound & $\mathrm{I}(1)$ Bound \\
$5 \%$ & 2.75 & 3.79 \\
$1 \%$ & 3.12 & $4.25^{\mathrm{b}}$ \\
\hline
\end{tabular}

Note: $\mathrm{a}, \mathrm{b}$ and $\mathrm{c}$ denotes the co-integration levels at $1 \%, 5 \%$, and $10 \%$ respectively. The lower and upper bounds at the $1 \%, 5 \%$, and $10 \%$ significance levels were provided directly in the output of the bounds test by the EVIEWS 10 software.

\subsection{Result of the long-run Analyses}

Table 6 reported the estimated coefficients of the long-run explanatory variables associated with economic growth. The coefficients of the estimated outcomes indicated that remittance and government expenditure were positively correlated and statistically significant to the dependent variable. Based on the result all other things being constant a $1 \%$ change in the remittances might cause an approximate a $0.38 \%$ change in the real GDP growth in the long run. The results provide an important insight into the Ethiopian economy was benefited significantly from the inflow of workers' remittances during the study periods. This finding corroborates with the results of (Tahir et al., 2015), who suggested that international remittances have been played a major role in the growth process for the receiving countries. Furthermore, it could increase the volume of the foreign currency reserves, which can help to stabilize the domestic economy for sustainable growth. In addition another empirical study (Meyer and Shera, 2016), who argued that international remittances have a strong positive effect on the support of the balance of payment, economic growth, saving and investment and improve domestic consumptions even in some countries this impact could increase more levels in the remittances than relative to the GDP. Likewise, (Goschin, 2014) concludes on the findings that international remittances had a key role to secure the household current consumption for the receiving household families as well as that would increase the individual household investment prospective with direct stimulates on the economic development for the remitted country. Moreover, our result is consistent with those of other studies (Adams and Cuecuecha, 2013; Imai et al., 2014; Makun, 2018; Meyer and Shera, 2016; Nyamongoa et al., 2012; Tahir et al., 2015), who generally suggested that international remittances were one of an external source of finance for boosting economic growth for remitted receiving countries.

Turning now to the empirical evidence on the government expenditure, the long-run coefficient showed positive and statistically significant at 0.05 level, which indicates that a $10 \%$ increase in government expenditure that could improve $8.6 \%$ raise on the GDP growth. Since the country is still developing; government expenditure could provide more pursue to the expansionary strategies to shape the socio-economic development overhead the country economy for a long period. Therefore, our result was strong evidence for increasing government expenditure supports a positive impact on the Ethiopian Economic growth. This result is similar to (Alkhathlan, 2013) a study of the case of Saudi Arabia and (Attari and Javed, 2013) the case of Pakistan.

The long-run estimated coefficients of the exports on the GDP growth show the positive relationship (Table 6), specifically a $1 \%$ increase in total exports an approximately may change in a $0.02 \%$ in the real GDP growth; nevertheless, this change does not have statistically significant. The findings of the current study are consistent with those of (Alkhathlan, 2013; Marwan et al., 2013; Tekin, 2012) who argue the existence of a long-run positive nexus between export, growth, and remittance hypotheses that stimulating remittance-led and export-led growth. Whereas, the long-run coefficients of rural population growth showing a negative association with the effect of 
the economic growth, which implies that a $1 \%$ increases in rural population growth might cause a $0.07 \%$, reduction in the real GDP growth. This result suggesting that the rural population growth is inimical to the economic growth in the long run in the case of Ethiopia. Briefly, rural population intensity is adversely related to economic growth during the study period. In other arguments, in the long period, the rise in the percentage of the rural population as the total may lead to the result in the decline of economic intensity. This provides evidence that the government of Ethiopia should have a focus to increase the urbanization of the country to reduce the population who lives in the rural area to improve society's standard of life.

Table 6: Estimated Long-run elasticities using the ARDL $(1,2,0,2,0,2)$ approach, the dependent variable is

$$
\triangle \mathrm{GDP}_{\mathrm{t}} \text {. }
$$

\begin{tabular}{llll}
\hline Independent variables & Coefficients & Standard error & P-values \\
\hline Constant & 0.9938 & 0.9432 & 0.3068 \\
Trend & 0.0635 & 0.0506 & 0.2268 \\
$\Delta \operatorname{lnWR}_{\mathrm{t}}$ & 0.3807 & 1.8484 & $0.0299^{* *}$ \\
$\Delta \operatorname{lnGE}_{\mathrm{t}}$ & 0.8574 & 6.0832 & $0.0638^{*}$ \\
$\Delta \operatorname{lnEXP}_{\mathrm{t}}$ & 0.0203 & 0.2182 & 0.7269 \\
$\Delta \operatorname{lnRPG}_{\mathrm{t}}$ & -0.0701 & 1.4059 & 0.6241 \\
$\Delta \mathrm{INF}_{\mathrm{t}}$ & -0.1489 & 0.0722 & $0.0548^{* *}$ \\
\hline
\end{tabular}

Note: $* * *, * *$ and $*$ indicate the significance level at, $0.01,0.05$ and 0.1 , respectively.

Likewise, the coefficient of inflation rate was adversely correlated with the GDP and significant effect in the estimated models which suggested that when the inflation rate rises by $10 \%$ point, the GDP growth decreased by about $1.4 \%$ during the study periods. Accordingly, the remittance and government expenditure approach might create to aggravate the inflation rate to have an inverse relation with the growth rate and hence might create uncertainty. This finding corroborates the ideas of (Abbas et al., 2017) who suggested that inflation has been a significant effect and inverse associations with economic growth in Pakistan.

Table 7: ECM for the selected ARDL model, the dependent variable is $\Delta \mathrm{GDPt}$

\begin{tabular}{llll}
\hline Independent variables & Coefficients & Standard error & P-values \\
\hline Constant & 0.0431 & 0.0253 & $0.0972^{*}$ \\
Trend & 0.1330 & 0.1064 & 0.2283 \\
$\Delta \operatorname{lnWR}_{\mathrm{t}}$ & 0.2532 & 0.9912 & $0.0015^{* * *}$ \\
$\Delta \operatorname{lnGE}_{\mathrm{t}}$ & 0.0425 & 0.4578 & $0.0726^{*}$ \\
$\Delta \operatorname{lnEXP}_{\mathrm{t}}$ & -0.2854 & -0.2116 & 0.4545 \\
$\Delta \operatorname{lnRPG}_{\mathrm{t}}$ & 0.3358 & 0.8580 & 0.9241 \\
$\Delta \mathrm{INF}_{\mathrm{t}}$ & -0.0918 & 0.0875 & 0.3090 \\
ECT $_{\mathrm{t}-1}$ & -0.9448 & 0.2082 & $0.0001^{* * *}$ \\
\hline Diagnostic test $_{\mathrm{R}-\mathrm{squared}}$ & & \\
$\mathrm{J}-\mathrm{B}$ & 0.81 & & \\
LM (2) & $1.39(0.49)$ & & \\
ARCH (1) & $0.43(0.65)$ & & \\
Ramsey's RESET (2) & $1.19(0.28)$ & & \\
& $1.18(0.19)$ & &
\end{tabular}

Note: $* * *, * *$, and $*$, represents the standard significance level at $0.01,0.05$ and 0.1 , respectively. The numbers in the parenthesis show the p-values. LM means the Lagrange multiplier test of the residual for the serial correlation. ARCH: stands for autoregressive conditional heteroscedasticity test of the residuals. Heteroscedasticity: This is based on the regression of squared residuals on squared fitted values. Normality is a test performed based on the skewness and kurtosis of the residuals.

\subsection{Analyses of the Causality results}

After confirming the series of all the variables were jointly cointegrated in the long- run, next the ECM was used to estimate within the ARDL framework and develop the coefficient of the short-run dynamics relationships between the series. The model of the ECM was established to examine the dynamics of the short- term associations among the economic growth and its instrumental determinant endogenous variables and to make sure the presence of the reliability of the stable long-run cointegration evaluated earlier in the bound test. The numerous components of the variables expressed in the ARDL model were replaced with the ECM equations. Table 7 presents the results of the short-run coefficients and its respective standard diagnostic tests estimated value of the ECM relationships between economic growth remittances and government expenditures with other control variables considered in the regression model.

The computed Wald test $\mathrm{p}$-values on the elasticity coefficients of the workers' remittance and the government expenditure were positive and statistically significant at $1 \%$ and $10 \%$ significance level, respectively. Therefore, 
the initial of the null hypothesis of no short-run Granger causality running from workers' remittance and government expenditure to economic growth was rejected, we conclude that in the effect of remittance and government expenditure Granger causes the economic growth in the short-periods. Hence, in the short-period, a $10 \%$ variation in remittance and government expenditure could lead to $2.5 \%$ and $0.42 \%$ change respectively, in the real GDP growth in Ethiopia during the study periods. However, there was a negative and statistically insignificant association between exports and inflation rate to economic growth which suggests that the two economic variables were an affront effect on economic growth in Ethiopia in the short periods. Whereas rural population growth had been a positive association to economic growth in the short-run but there was no statistically significant effect for growth.

Furthermore, the estimated coefficient of the lagged ECT appeared with the expected negative sign and statistically significant 0.01 levels, which indicates that the short-term deviation from the long-run equilibrium relationship might be corrected fast at any time when there is disequilibrium in the economy. The computed coefficient value of the ECT (-0.9448) denoted that around $94 \%$ of the short-run shocks in the current periods in the system would be returned to the long-run equilibrium in the following period (after one year since our study used to the data annual time series frequency). In other words, it might take approximately eleven months to convergence the stable long-run equilibrium after the system shocked detected in the earlier periods.

Additionally, the standard of the short-run model diagnostic tests was performed to validate whether the ECM term was well specified in the predictable regression assumptions. Accordingly, the R-squared, the normality, the serial correlation, and the heteroscedasticity $(\mathrm{ARCH})$ tests were checked. Therefore, the value of the $\mathrm{R}^{2}$ was 0.81 , which implies that the independent variables explained in the system were only $81 \%$ of from the total information considered inside the model in the short term, and the other $19 \%$ factors may explain outside the models were not included. The test result of the Lagrange multiplier (LM) discloses that no indications of the serial correlations in the residuals inside the model. The normality test of the Jarque-Bera shows that the residuals were normally distributed in the model (Table 7).

In addition, it is also probable that the data of the macroeconomic variables might be questioned to have structural breaks, particularly the inflows of international workers' remittances due to the cause of the period of the ensuing financial crisis between 2007- 2008 were included in our sample periods. Therefore, to verify the stability of the estimated short-run parameters, we tested through plotting the normal cumulative sum (CUSUM) and the cumulative sum of square CUSUMSQ) tests suggested by (Appiah, 2018; Brown et al., 1975). To use the Chow stability and reliability tests are needed prior knowledge of the specific time periods for the structural breaks in the estimation procedure, whereas the normal CUSUM and the CUSUMSQ tests do not need any prior knowledge of when the structural breaks could occur (Alkhathlan, 2013; Ozturk and Acaravci, 2013). Figure3 (a) and (b) present the plotted of the reliable CUSUM and CUSUMSQ test indicators, which is stays between the critical value bounds of the standard 0.05 significance level. This plot finding suggested that the estimated shortrun coefficients were stable over the study periods.

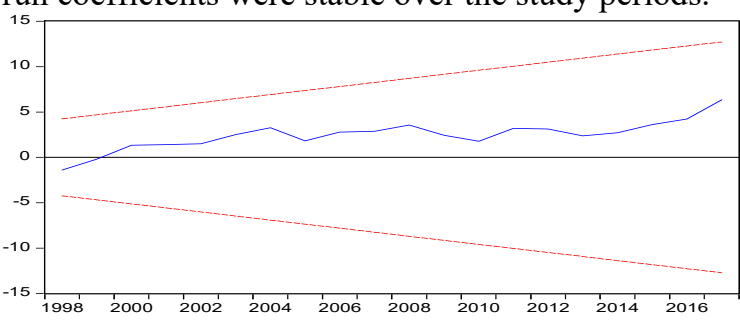

(a) CUSUM test

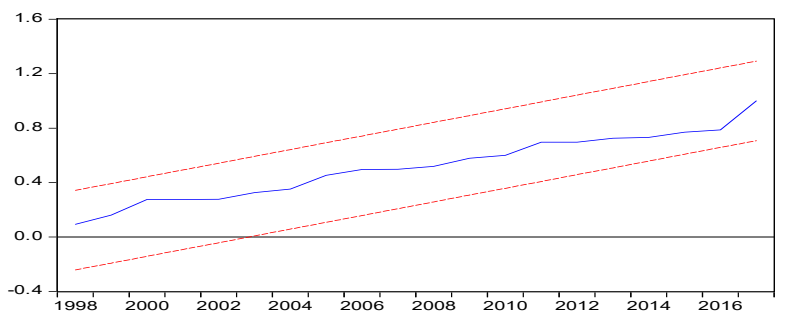

(b) CUSUMSQ test

Figure3. Plots of stability tests of recursive estimates (OLS) using the CUSUM test and the CUSUM of squares test.

Finally, for the aim of causality, we further employed the recent version of the non-Granger causality test modified by (Toda and Yamamoto, 1995) method to make the robustness of our findings of the causality deficiencies from the ARDL framework between the variables. The Granger non-causality test results reported in Table 8. As described earlier in the method part, the key of the initial step was to estimate the DGP of all the series of the variables to determine the optimal order of integration $\left(\mathrm{d}_{\max }\right)$ and the optimum lag lengths for the VAR augmented. Overall, based on the results of the unit root test the series of the variables were known to be I (1), therefore the optimal order of integration was taken as one $\left(\mathrm{d}_{\max }=1\right)$, and the maximum lag lengths was $(\mathrm{k}=1)$ and the VAR augmented estimation was $\left(\mathrm{k}+\mathrm{d}_{\max }\right)$ selected depending on the minimum result of the lag length selection criteria. 
Table 8: The Granger non-causality test results

\begin{tabular}{|c|c|c|c|}
\hline Null Hypothesis & F-Statistic $\left(\mathrm{X}^{2}\right)$ & $\mathrm{P}$-value & Decision \\
\hline $\operatorname{lnWR}_{t} \rightarrow \mathrm{GDP}_{\mathrm{t}}$ & 6.0858 & 0.0030 & Reject $^{\mathrm{b}}$ \\
\hline $\mathrm{GDP}_{\mathrm{t}} \mapsto \ln \mathrm{WR}_{\mathrm{t}}$ & 0.0437 & 0.6876 & $A c c e p t^{a}$ \\
\hline $\operatorname{lnGE} E_{t} \mapsto G D P_{t}$ & 8.7168 & 0.0333 & Reject $^{b}$ \\
\hline $\mathrm{GDP}_{\mathrm{t}} \mapsto \operatorname{lnGE} \mathrm{E}_{\mathrm{t}}$ & 0.70591 & 0.5575 & Accept $^{\mathrm{a}}$ \\
\hline $\operatorname{lnEXP} P_{t} \mapsto \mathrm{GDP}_{t}$ & 3.03034 & 0.0481 & Reject $^{b}$ \\
\hline $\operatorname{lnRPG}_{\mathrm{t}} \mapsto \mathrm{GDP}_{\mathrm{t}}$ & 0.92102 & 0.4450 & Accept $^{\mathrm{a}}$ \\
\hline $\mathrm{GDP}_{\mathrm{t}} \mapsto \operatorname{lnRPG} \mathrm{G}_{\mathrm{t}}$ & 0.57995 & 0.6336 & $\mathrm{Accept}^{\mathrm{a}}$ \\
\hline $\mathrm{INF}_{\mathrm{t}} \rightarrow \mathrm{GDP}_{\mathrm{t}}$ & 2.30329 & 0.1004 & Accept $^{\mathrm{a}}$ \\
\hline $\mathrm{GDP}_{\mathrm{t}} \rightarrow \mathrm{INF}_{\mathrm{t}}$ & 0.64468 & 0.5933 & $\mathrm{Accept}^{\mathrm{a}}$ \\
\hline
\end{tabular}

Diagnostic tests

$\operatorname{LM}(3) \quad 0.76(0.78)$

J-B Normality(3) $0.52(0.76)$

$\mathrm{ARCH}(1) \quad 1.50(0.28)$

The causality test result was presented in the table used by the Toda and Yamamoto (1995)

Note: $\mapsto$ represents does not Granger Cause a, b and c indicate significance at 1\%, 5\%, and 10\% respectively. LM: Lagrange multiplier test of residual serial correlation. ARCH: autoregressive conditional heteroscedasticity test of residuals. Heteroscedasticity: This is based on the regression of squared residuals on squared fitted values. Normality is based on a test of skewness and kurtosis of residuals.

The standard Wald test contingent on the asymptotic distribution was conducted on the various variables of the coefficients to test for the TY no Granger causality. As the long-run model the computed p-values of the variables remittance and government expenditures were (0.02) and (0.06), respectively. Hence, these p-values were below the standard significance level at 5\% and $10 \%$ remittance and government expenditures, respectively. Therefore, the null hypothesis of no Granger causality from remittance to economic growth and from government expenditure to the economic growth was rejected at a strong causality test level. However, under extending the assumption of the TY Granger causality model, the null hypothesis of no Granger causality running from economic growth to remittance and economic growth to government expenditure at the $1 \%$ significance level was accepted. As a result, there are unidirectional Granger causality running from workers' remittance to economic growth and government expenditure to economic growth. These results suggested that remittance and government expenditures were the determinant factor for economic growth and hence, economic growth was the function of both remittance and government expenditure. Accordingly, workers' remittance has the potential to help Ethiopian economic growth and thus the policies should have to be improved by the Ethiopian policy-makers to have further emphasized for the international workers' remittance inflows to increase the volume of the remittance. These granger causality results also further supported by the short-run models therefore the results reported in our model were robust. Again, the model passes all the standard diagnostics test for normality, serial correlation, and heteroscedasticity test (Table 8).

\section{Concluding Remarks}

The causal associations between GDP growth, remittance, and government expenditure in Ethiopia were determined from 1982 -2017 using the ARDL and Granger-causality framework by considering export, rural population growth and inflation rate as an additional control variable to the remittance-economic growth nexus. To perform this, we applied the following procedures. First, we employed the ADF, PP, and ADF-GLS tests for the unit root properties of the variables undertaken on the study thus we found the mixture of integrated of the order of the variables I(1) and I(0). Secondly, we used the Johansen-Juselius, Johansen cointegration, and the ARDL bound approach for the long-run cointegration test thus, both results confirm that all the variables were jointly cointegrated in the long run. Third, we applied the modified form of the TY Granger causality technique, which is well-known and more valid irrespective of whether the variables of the series are $\mathrm{I}(0), \mathrm{I}(1)$ or $\mathrm{I}(2)$, cointegrated or non-cointegrated of any an arbitrary order.

The ARDL result shows that the inflows of remittances have a positive and statistically significant effect both the long and short-term on the economic growth in Ethiopia during the study periods. This implies that most of the Ethiopian overseas migrant worker earnings are remitted to their families for the aim of household consumption and investment activities in their home country. In the same way, the results determined that government expenditures have a positive relation and significant effect both the long and short-run. Therefore, economic growth in Ethiopia is being determined by the remittance and the government expenditure fiscal strategies that could use to establish the basic tools for infrastructure to build the economy. The government policies should emphasize to enhance economic growth by focusing to increase in the inflows of incoming remittance, improving 
the government expenditure, reduce the rural population growth and inflation rate in the country. Especially remittance, export revenues could help to improve the government fiscal policies and might enhance the purchasing power of the economy.

Furthermore, the TY Granger non-causality causality test result founds significant unidirectional causality running from government expenditure to the economic growth and unidirectional causality running from export to the GDP growth. These causality results describe that the hypothesis of growth which assumes that the inflows of remittance, government spending, and exports were the main determinant factor of economic growth in Ethiopia during the study periods and consequently, economic growth was a function of remittance, export, and government expenditure. The results of the study are significant for a policy perspective since the findings contribute to the growing opinion in the empirical literature that the remittances have a positive effect on economic growth by reducing the foreign currency shortage and improving government investment in physical capital.

Appendix Table 1: Lag Selection Criteria for the Augmented VAR and model diagnostics test statistics.

\begin{tabular}{cccccccl}
\hline Lag & LGKL & LR & FPE & AIC & SC & HQ & $\begin{array}{l}\text { LM test for serial } \\
\text { correlation }\end{array}$ \\
\hline 1 & -199.6970 & 49.79297 & 0.249975 & 15.59335 & $17.53617^{\text {a }}$ & 16.22666 & $0.6059(0.9364)$ \\
2 & -165.1385 & 40.13238 & 0.364125 & 15.68636 & 19.29445 & 16.86251 & $2.0288(0.0319)$ \\
3 & -129.5868 & 27.52392 & $0.901111^{a}$ & 15.71528 & 20.98865 & 17.43426 & $0.7692(0.7882)$ \\
4 & -14.91853 & 44.38771 & $0.069723^{\text {a }}$ & $10.63991^{\text {a }}$ & 17.57855 & $12.90173^{\text {a }}$ & $0.8623(0.6733)$ \\
\hline
\end{tabular}

${ }^{a}$ Denotes the lag selected by a criterion.

Conflict of interest: The authors declare that they have no conflict of interest.

\section{References}

Abbas, F., Masood, A., Sakhawat, A., 2017. What determine remittances to Pakistan? The role of macroeconomic, political and financial factors. J. Policy Model. 39, 519-531. https://doi.org/10.1016/j.jpolmod.2017.03.006

Adams, R.H., Cuecuecha, A., 2013. The Impact of Remittances on Investment and Poverty in Ghana. World Dev. 50, 24-40. https://doi.org/10.1016/j.worlddev.2013.04.009

AfDB, 2019. African economic outlook 2019. Macroeconomic performance and prospects, Jobs, growth, and firm dynamism. Integration for Africa's economic prosperity. www.afdb.org/fileadmin/uploads/afdb/Documents/Publications/African_Economic_Outlook_2018_EN.pdf

Alkhathlan, K.A., 2013. The nexus between remittance outflows and growth: A study of Saudi Arabia. Econ. Model. 33, 695-700. https://doi.org/10.1016/j.econmod.2013.05.010

Amega, K., 2018. Remittances, education and health in Sub-Saharan Africa. Cogent Econ. Financ. 6, 1-27. https://doi.org/10.1080/23322039.2018.1516488

Appiah, M.O., 2018. Investigating the multivariate Granger causality between energy consumption, economic growth and CO2 emissions in Ghana. Energy Policy 112, 198-208. https://doi.org/10.1016/j.enpol.2017.10.017

Asatryan, Z., Bittschi, B., Doerrenberg, P., 2017. Remittances and public finances: Evidence from oil-price shocks. J. Public Econ. 155, 122-137. https://doi.org/10.1016/j.jpubeco.2017.09.009

Attari, M.I.J., Javed, A.Y., 2013. Inflation, Economic Growth and Government Expenditure of Pakistan: 19802010, in: Procedia Economics and Finance. Elsevier B.V., pp. 58-67. https://oi.org/10.1016/s22125671(13)00010-5

Bang, J.T., Mitra, A., Wunnava, P. V., 2016. Do remittances improve income inequality? An instrumental variable quantile analysis of the Kenyan case. Econ. Model. 58, 394-402. https://doi.org/10.1016/j.econmod.2016.04.004

Beyene, B.M., 2014. The Effects of International Remittances on Poverty and Inequality in Ethiopia. J. Dev. Stud. 50, 1380-1396. https://doi.org/10.1080/00220388.2014.940913

Bove, V., Elia, L., 2017. Migration, Diversity, and Economic Growth. World Dev. 89, $227-239$. https://doi.org/10.1016/j.worlddev.2016.08.012

Brown, R.L., Durbin, J., Evans, J.M., 1975. Techniques for Testing the Constancy of Regression Relationships over Time. J. R. Stat. Soc. Ser. B 37, 149-192. https://doi.org/10.2307/2984889

Brunow, S., Nijkamp, P., Poot, J., 2015. The impact of international migration on economic growth in the global economy, 1st ed, Handbook of the Economics of International Migration. Elsevier B.V. https://doi.org/10.1016/B978-0-444-53768-3.00019-9

Cadena, B.C., Duncan, B., Trejo, S.J., 2015. The labor market integration and impacts of US immigrants, 1st ed, Handbook of the Economics of International Migration. Elsevier B.V. https://doi.org/10.1016/B978-0-44453768-3.00022-9

Cooper, B., Esser, A., 2018. Exploring barriers to remittances in sub-Saharan Africa series. Volume 4. Remittances in Ethiopia. https://cenfri.org/wp-content/uploads/2018/11/Barriers-study-volume-4-Remittances-in- 
Ethiopia_November-2018.pdf

Engle, R.F., Granger, C.W.J., 1987. Co-Integration and Error Correction: Representation, Estimation, and Testing. Econometrica 55, 251. https://doi.org/10.2307/1913236

Goschin, Z., 2014. Remittances as an Economic Development Factor. Empirical Evidence from the CEE Countries, in: Procedia Economics and Finance. Elsevier B.V., pp. 54-60. https://doi.org/10.1016/s22125671(14)00277-9

Granger, C.W.J., 1981. Some properties of time series data and their use in econometric model specification. J. Econom. 16, 121-130. https://doi.org/10.1016/0304-4076(81)90079-8

Granger, C.W.J., Weiss, A.A., 1983. Time Series Analysis of Error-Correction Models. Stud. Econom. Time Ser. Multivar. Stat. 255-278. https://doi.org/10.1016/B978-0-12-398750-1.50018-8

Granger, J., C.W., 1969. Investigating Causal Relations by Econometric Models and Cross-spectral Methods. Econometrica 37, 424-438. http://dx.doi.org/10.1787/5js331fw0xxn-en.

Imai, K.S., Gaiha, R., Ali, A., Kaicker, N., 2014. Remittances, growth and poverty: NEW evidence from Asian countries. J. Policy Model. 36, 524-538. https://doi.org/10.1016/j.jpolmod.2014.01.009

Johansen, S., 1988. Statistical analysis of cointegration vectors. J. Econ. Dyn. Control 12, $231-254$. https://doi.org/10.1016/0165-1889(88)90041-3

Johansen, S., Juselius, K., 1990. Maximum Likelihood Estimation and Inference on Cointegration- With applications to the demand for money. https://doi.org/10.1111/j.1468-0084.1990.mp52002003.x

Kumar, R.R., 2013. Remittances and economic growth: A study of Guyana. Econ. Syst. 37, $462-472$. https://doi.org/10.1016/j.ecosys.2013.01.001

Makun, K.K., 2018. Imports, remittances, direct foreign investment and economic growth in Republic of the Fiji Islands: An empirical analysis using ARDL approach. Kasetsart J. Soc. Sci. 39, 439-447. https://doi.org/10.1016/j.kjss.2017.07.002

Marwan, N.F., Kadir, N.A.A., Hussin, A., Zaini, A.A., Ab.Rashid, M.E., Helmi, Z.A.G., 2013. Export, Aid, Remittance and Growth: Evidence from Sudan, in: Procedia Economics and Finance. Elsevier B.V., pp. 310. https://doi.org/10.1016/s2212-5671(13)00211-6

Matouš, P., Todo, Y., Mojo, D., 2013. Roles of extension and ethno-religious networks in acceptance of resourceconserving agriculture among Ethiopian farmers. Int. J. Agric. Sustain. 11, 301-316. https://doi.org/10.1080/14735903.2012.751701

Mavrotas, G., Kelly, R., 2001. Old Wine in New Bottles: Testing Causality between Savings and Growth. Manchester Sch. 69, 97-105. https://doi.org/10.1111/1467-9957.69.s1.6

Meyer, D., Shera, A., 2016. The impact of remittances on economic growth: An econometric model. EconomiA 18, 147-155. https://doi.org/10.1016/j.econ.2016.06.001

MOFED, 2010. Growth and transformation plan 2010/11-2014/2015. Resource document. Ministry or Finance and Economic Development November 2010 Addis Ababa.

NBE, 2018. National Bank of Ethiopia, 2018 annual report. http://www.nbe.gov.et/pdf/annualbulletin/Annual\%20Report\%202017-2018/201718\%20annual\%20report.pdf

NBE, 2010. National Bank of $\quad$ Ethiopia, annual report. http://www.nbe.gov.et/pdf/annualbulletin/Annual\%20Report\%202010-2011/Annual\%20Report\%2020102011.pdf

NBE, 2006. National Bank of Ethiopia Annual Report 2005/06 Governors. http://www.nbebank.com/pdf/annualbulletin/Annual\%20Report\%202005_06/Governors\%20Notes.pdf

Newbold, C.W.J.G. and P., 1974. Spurious Regressions in Econometrics. J. Econom. 2 111-120 2, $111-120$. https://doi.org/10.1016/0304-4076(74)90034-7

Nyamongoa, E.M., Misatib, R.N., Kipyegonb, L., Ndirangu, L., 2012. Remittances, financial development and economic growth in Africa. J. Econ. Bus. 64, 240-260. https://doi.org/10.1080/15228916.2017.1301162

Ozturk, I., Acaravci, A., 2013. The long-run and causal analysis of energy, growth, openness and financial development on carbon emissions in Turkey. Energy Econ. 36, 262-267. https://doi.org/10.1016/j.eneco.2012.08.025

Pesaran, M.H., Shin, Y., Smith, R.J., 2001. Bounds testing approaches to the analysis of level relationships. J. Appl. Econom. 16, 289-326. https://doi.org/10.1002/jae.616

Rao, B.B., Takirua, T.B., 2010. The effects of exports, aid and remittances on output: The case of Kiribati. Appl. Econ. 42, 1387-1396. https://doi.org/10.1080/00036840701721331

Tahir, M., Khan, I., Shah, A.M., 2015. Foreign Remittances, Foreign Direct Investment, Foreign Imports and Economic Growth in Pakistan: A Time Series Analysis. Arab Econ. Bus. J. 10, 82-89. https://doi.org/10.1016/j.aebj.2015.06.001

Tekin, R.B., 2012. Economic growth, exports and foreign direct investment in Least Developed Countries: A panel Granger causality analysis. Econ. Model. 29, 868-878. https://doi.org/10.1016/j.econmod.2011.10.013 
The World Bank, 2018. Migration and Remittances - Migration and Development Brief 29.

The World Bank, 2011a. Migration and Remittances Factbook 2011, 2nd Editio. ed. The World Bank, Washington DC 20433.

The World Bank, 2011b. Remittance Markets in Africa, Remittance Markets in Africa. Washington DC 20433. https://doi.org/10.1596/978-0-8213-8475-6

United, N., 2017. Department of Economic and Social Affairs, Population Division (2017). International Migration Report 2017: Highlights (ST/ESA/SER.A/404). https://doi.org/10.18356/5e2626a2-en

Vargas-Silva, C., 2008. Are remittances manna from heaven? A look at the business cycle properties of remittances. North Am. J. Econ. Financ. 19, 290-303. https://doi.org/10.1016/j.najef.2008.03.001

Wolde-Rufael, Y., 2010. Coal consumption and economic growth revisited. Appl. Energy 87, 160-167. https://doi.org/10.1016/j.apenergy.2009.05.001

Wolde-Rufael, Y., 2005. Energy demand and economic growth: The African experience. J. Policy Model. 27, 891903. https://doi.org/10.1016/j.jpolmod.2005.06.003

Y.Toda, H., Taku Yamamoto, 1995. Statistical Inference in Vector Autoregressions with Possibly Integrated Processes. J. Econom. 66, 225-250. http://dx.doi.org/10.1016/0304-4076(94)01616-8 